How to Cite

Surya, I. P. A. K. (2019). Chemical on pleurotusostreatus. International Journal of Chemical \& Material Sciences, 2(1), 8-13.

https://doi.org/10.31295/ijcms.v2n1.72

\title{
Chemical on Pleurotusostreatus
}

\author{
I Putu Arya Kresna Surya \\ LKP Science Scholar, Denpasar, Indonesia \\ Email: aryakresnasurya@gmail.com
}

\begin{abstract}
Oyster mushroom (Pleurotusostreatus) is a fungus that is much-loved by the people. In addition to deliciousness, oyster mushrooms are also very beneficial for health. High nutritional content with a variety of essential amino acids contained therein, oyster mushrooms also contain other compounds that are important for the medical aspects. The more days of oyster mushrooms increasingly interested in the community, this is apparently a result of the impact of increasing public awareness of the benefits and nutritional value of oyster mushrooms. In nature, Oyster mushroom grows only in certain seasons in limited quantities so that the oyster mushroom has good prospects to be cultivated. Mushrooms Lampung is a business that is engaged in the cultivation of oyster mushrooms. The oyster mushroom is grown on the media can be sawdust packed in plastic bags. In the oyster mushroom cultivation activities include preparation of tools and materials, raw material preparation, mixing media, composting, pasteurization, inoculation, incubation, growth and maintenance, harvesting, post-harvest, and marketing. The pasteurization process using oyster mushrooms media banker and a vessel of water.
\end{abstract}

Keywords---medicine, place, pleurotusostreatus, powder wood, seeds.

\section{Introduction}

Oyster mushroom (Pleurotus ostreatus) is so named because of its shapes like oysters or mushroom users. Oyster mushrooms are woody mushrooms growing side by side on weathered logs. This mushroom has a body fruit that grows in bloom forms a shallow funnel such as shells. But some call it West Mushroom. There are several types of oyster mushrooms namely milk white oyster mushrooms, pink oyster mushrooms, gray oyster mushrooms, and brown oyster mushroom. White oyster mushrooms are best known for being delicious and liked community (Sumarmi, 2006).

Oyster mushrooms are one of the many healthy vegetables known and consumed. White oyster mushroom is a mineral source well, the main mineral content is $\mathrm{K}, \mathrm{Na}, \mathrm{P}, \mathrm{Ca}$, and $\mathrm{Fe}$, oyster mushrooms too efficacious to reduce cholesterol levels, prevent diabetes, and play a role as anti-cancer (Cahyana and Mucrodji, 1999). In this day and age many people have cultivated mushrooms white oysters, white oyster mushroom cultivation besides adding to the economy of the farmer, it turns out that white oyster mushrooms are beneficial to the body because there are many contains vitamins and amino acids. enough white oyster mushroom cultivation easy does not require media that is difficult enough with the main media namely sawdust.

White oyster mushroom (Pleurotus ostreatus) is one type of mushroom consumption is quite popular with the community and also useful for the body because of high nutritious and low fat. White oyster mushrooms are included in the group Basidiomycetes, which is a group of white rot fungi that are characterized by the growth of white mycelium pales on the entire growing media (Sumarsih, 2010). White oyster mushroom is a type of wood mushroom that has higher nutrient content than other types of woody mushrooms. White oyster mushrooms contain protein, fat, phosphorus, iron, thiamin and riboflavin is higher than other types of mushrooms (Djarijah and Abbas, 2001).

White oyster mushrooms (Pleurotus ostreatus) are currently quite popular and much loved by people in the world, besides delicious, it also feels full of nutrient content, high protein, and low fat. Every $100 \mathrm{~g}$ of dried mushrooms contains 7.8-17.72 $\mathrm{g}$ of protein, 1-2.3 $\mathrm{g}$ of fat, 5.6-8.7 $\mathrm{g}$ of crude fiber, Ca $21 \mathrm{mg}, \mathrm{Fe} 32 \mathrm{mg}, 0.21 \mathrm{mg}$ thiamin, riboflavin $7.09 \mathrm{mg}$, and 57.6-81.8 g carbohydrates, with 328-367 kcal of energy. This mushroom has the ability to

ISSN 2632-9468

Received Jan 20, 2019 / Accepted Jun 18, 2019 / Published Jul 05, 2019 
improve metabolism and regulate autonomic nerve function. In addition, it is also for the treatment of hepatitis, digestion, duodenum, and stomach. A source of food with high protein content known by the community is soybeans which are processed into tempeh or tofu (Ginting, et al., 2013). But recently the soybean has increased price, in response to this, the community needs other alternatives. When viewed from the protein content, oyster mushrooms can be another choice as a protein source needed by the body. According to Parjimo and Agus Andoko (2013) protein content of oyster mushrooms every $100 \mathrm{~g}$ by $27 \%$ while the protein in soybean tempe is $18.3 \%$ every $100 \mathrm{~g}$ (Muchtadi, 2010).

Oyster mushrooms include perishable foods, such as types other vegetables. A few days after harvest, the quality of the oyster mushroom drops with fast to not be consumed. Changes in the quality of oyster mushrooms, among others withered, the color becomes brown, soft and tastes change, in Indonesia mushroom preservation of commercial food has not been done much, in the supermarket, mushrooms are usually stored in cold temperatures, namely 15-200C. At this temperature, mushrooms can only survive (still suitable for consumption) for 3-5 days, though has been packed with polyethylene plastic (Ardiansyah et al., 2014).

In the research, Netty mentioned the process of making mushroom powder oysters are considered quite important optima, because oyster mushrooms have the potential as nutriceutical and in his research mention the results of nutritional analysis on white oyster mushrooms $(100 \mathrm{~g})$ indicating that crude fiber $(3.44 \% \mathrm{~b} / \mathrm{b})$, protein $(3.15 \% \mathrm{~b} /$ b), glutamic acid $(0.94 \%$ b / b) is relatively high. Carbohydrates $(0.63 \%$ b / b), fat $(0.10 \%$ b / b), relatively low (Netty, 2004). The temperature and drying times are right for the manufacturing process White oyster mushroom flour is $60^{\circ} \mathrm{C}$ with 11 hours drying time. Results of analysis of protein and water levels from a combination of temperature $60^{\circ} \mathrm{C}$ for a long time drying 11 hours, obtained protein content of $16.95 \%$ and water content amounting to $13.15 \%$. These results are in accordance with the Indonesian National Standards for flour that meets the standard protein content of $7 \%$ and the water content of $14.5 \%$ (Gea, 2014). In the Hapsari study, the soaking material was influential real water content, fat, crude fiber and amylographic properties of banana flour. The soaking material did not significantly affect the receptivity of banana flour cholesterol. The use of calcium carbonate (CaCO3) soaking material has time and the thermalization temperature and viscosity of banana flour are lower than sodium metabisulfite (NaS2O5) (Hapsari, 2012).

\section{Methodology}

Oyster mushroom cultivation is very suitable for tropical regions such as Indonesia. The investment needed to start the cultivation of oyster mushrooms is quite cheap and can be done gradually. The hardest part is making baglog, a planting medium that has been inoculated with mushroom seeds. The Latin name of the oyster mushroom is Pleurotus ostreatus, including in the Basidiomycota group. Oyster mushrooms are called because the shape of the crown resembles oyster skin. Semicircular white. In the wild, white oyster mushrooms are commonly found in decayed logs. Maybe because of that, oyster mushrooms are often called wood mushrooms.

There are two main activities in the cultivation of oyster mushrooms. The first step is to make the planting media and inoculate the mushroom seeds into the growing media. So that the media overgrown with white mycelium like cotton. The second stage is to grow the mycelium into a fruiting body. For newcomers, usually, start cultivation activities by growing baglog into fruit flesh. While procurement, baglog that is ready to grow is obtained by buying from another party. Then after the cultivation effort developed and the volume was large, I just tried to make baglog myself.

\section{Preparation of Oyster Mushroom Planting}

Before planting, the things that support the cultivation of oyster mushrooms must be available, including home baglog, baglog shelves, oyster mushroom seeds, and cultivation equipment. (Can you see articles Preparation Oyster Mushroom Cultivation). Keep the oyster mushroom cultivation using certified seed that can be purchased from other farmers or the local agricultural bureau. Equipment oyster mushroom cultivation is quite simple, affordable prices, we can capitalize even kitchen appliances.

To optimize the results in the cultivation of oyster mushrooms in the lowlands can be done with the modification to the media material and measuring, ie, by adding or reducing the dose of each ingredient of the general standard. In a small-scale business, experiments in determining the dose of media materials are very important in order to obtain the right dose. This is because the fungus is cultivated in different growing environments necessarily require nutrients and different media depending on local environmental conditions. Up to now, there is no standard media 
composition for oyster mushroom cultivation in the lowlands so that farmers modify the media and the environment based on the experience and condition of each.

As the oyster mushroom growing medium, sawdust serves as a provider of nutrients for fungi. The wood used should hardwood sawdust for the kind of great potential for increasing crop yields oyster mushrooms. This is because the hardwood contains a lot of cellulose needed by the fungus. The types of hardwood that can be used as a medium for oyster mushroom growing among others wood village, and mahogany. To get the sawdust farmers must get it in place sawmill. Before being used as a medium usually powder timber to be composted first in order to break down into simpler compounds that are easily digested by the fungus. Sawdust composting process is done by closed using a plastic or a tarp for 1-2 days. Composting takes place with both a temperature rise of about 50 degrees C.

\section{Sterilization Material}

Before being mixed with other media, assault and bran sterilized timber beforehand using the oven for 6-8 hours at a temperature of 100 degrees $\mathrm{C}$. In addition to the reduced sterilization of microorganisms that cause contradictive also less water content in sawdust. Thus, the media becomes drier. Both materials are mixed and given then approximately 50-60\% water until the dough becomes smooth and can be clenched. Waterworks in the absorption of nutrients by the mycelium. Water used to clean water to reduce the risk of contamination of other organisms in the media. In the media into the plastic, the media should be completely solid so many mushrooms can be generated. So make sure that the ingredients have been pretty solid in plastic by means of pressing the dough until completely solid, then the top ring mounted PVC bag and then a plastic bag closed with cotton stoppers and secured with rubber.

\section{Sterilization Baglog}

Baglog sterilization is done by inserting baglog to autoclave or heater/steamer with a temperature of 121 degrees $\mathrm{C}$ for 15 minutes. To change the use of an autoclave or streamer, can use a large capacity drum with or able to accommodate about 50 baglog and heated on a stove oil or can also use the oven. Indeed, sterilization baglog use drum takes longer, which is about 8 hours but is considered savings. After the sterilization process is completed, baglog then cooled, by turning off the sterilizer and let the temperature go down little by little. After the cooling process, then planting seedlings mushroom.

\section{Planting and Maintenance of Oyster Mushrooms}

One of the critical success oyster mushroom cultivation is cleanliness in the process of cultivation, good cleanliness of the place, the tool, as well as workers. This is because cleanliness is absolute must be met. For that, a place for planting should be cleaned first with a broom, floor and walls are cleaned with disinfectant. The tools used for planting should also be sterilized using alcohol and heated over a candle flame. In addition, during the planting of the workers also ideally using a mask. It aims to minimize contamination.

In the oyster mushroom cultivation things must also be considered is to keep the room temperature and humidity in order to remain at the required standards. If the weather is dry, hot or windy, it will affect the temperature and humidity in the mushroom house so that the water quickly evaporates. If so, watering frequency should be increased. If the temperature is too high and the humidity is less, can make the body fungus is difficult to grow or not grow. Therefore, also set air circulation inside kumbung so the fungus does not quickly wither and die. Circulation arrangements can be made by partially closing circulation holes when the wind was strong. Circulation can be opened all when the wind is in the normal speed. However, the important thing is not to mushroom lacked fresh air.

\section{Pest Control Disease in Raising Oyster Mushroom}

In addition to maintenance baglog, the oyster mushroom cultivation is also necessary treatments to prevent or control pests and diseases that may strike the oyster mushroom. Pests and diseases that attack the oyster mushroom are certainly influenced by environmental or fungus itself. So between the cultivation of the one and the other, pest attack is likely to vary. 


\section{Hama Disease Mushroom Oyster \\ Caterpillar}

The caterpillars are pests most commonly found in oyster mushroom cultivation. There are three factors causing the emergence of these pests are factors moisture, dirt from the rest of the base/tubers or stems mold and mildew are not harvested, as well as the unsanitary environment.

Caterpillar pests arise when excessive air humidity. Therefore, caterpillar pests are common during the rainy season. Prevention is the best solution to overcome these pests is to regulate air circulation. You do this by opening circulation holes and temporarily halted watering process.

The base of the mushroom left in the harvesting baglog can cause small animals like ladybugs. Ladybug is the primary cause of caterpillar pests. While the mushrooms are harvested not likely because the fungus does not appear out so missed when harvesting and become rotten. This led to the emergence of caterpillars. Preferably, when harvesting baglog has confirmed it clean so that there is no base or stem and fungi that are not harvested.

Caterpillars may arise because of the house mushroom house or around kumbung. For example their cattle sheds or plant around the house kumbung. To prevent and overcome caterpillar pests, cleaning of the house and around the house mushroom house by spraying formalin.

Ants, Spiders, and Kleket (A Type of Mollusc)

Mechanically pest ants and spiders can be resolved by dismantling the nest and doused with kerosene. While the Chemish these pests can be controlled by spraying insecticides. This method is the last way and tries to avoid using insecticides if the attack is not severe because mushroom products are organic products. Advantage if the eradication of insect pests is done by mechanical means, among others, can cut costs during the treatment and also environmentally friendly. Meanwhile, pest baglog often found in the mouth. To control it is done by mechanical means, which is picked by hand.

\section{Growth of Fungus or Other Mushroom}

Another fungus that often interferes with oyster mushroom is Mucor sp., Rhizopus sp., Penicillium sp., And Aspergillus sp. on a substrate or baglog. The attack fungi are pathogenic mycelium is marked by the emergence of black, yellow, green, and the emergence of slime on the substrate. The resulting mycelium-mycelium oyster mushroom growth stunted growth or even not at all. This disease can be caused by environmental and media-making equipment during planting less clean or because the environment is a too moist mushroom house. To cope with this disease, the environment, and equipment at the time of making media and plantings need to be kept clean. Humidity in kumbung also arranged so as not to overdo it. This disease can attack baglog that have been opened or still closed. If baglog already attacked it must immediately be destroyed in a way removed from kumbung then burned. stalk Aft

This disease is a physiological disease characterized by an elongated mushroom stalk with a small mushroom body can not be fully developed. Elongated stalk diseases caused by excess CO2 as a result of the air vents is less than perfect. To avoid this disease should be carried out in kumbung ventilation settings as optimally as possible.

\section{Harvest and Post-Harvest}

Harvesting is a farming activity that always awaited by businesses. To obtain optimal results, the planting during harvest and post-harvest should be done well.

\section{Time and How to Harvest Mushroom}

The oyster mushroom cultivation including the types of plants that have a fairly quick harvest. Oyster mushroom harvest can be done within a period of 40 days after seeding or after fruiting body growing up, which is about 2-3 weeks after fruiting bodies are formed. The development of fruiting bodies of oyster mushrooms maximum marked also by sharping the edge of the mushroom. Criteria mushrooms eligible to be harvested is a fungus that is large enough and trimmed pointy but not yet in full bloom or not ruptured. Mushrooms with this condition will not be damaged if it is harvested. There are several requirements that must be met when the product is marketed, eg, uniformity of weight and size of the oyster mushroom. 


\section{Post-Harvest Handling Oyster Mushrooms}

Handling is done after harvesting the oyster mushroom aims to create the end result is a good quality in accordance with market demand. Here are some steps that oyster mushrooms produced products of good quality.

\section{Sorting}

Mushrooms are harvested must be immediately washed with clean water, then his body parts were separated from base. Washing and separation process is important because if, during the cultivation process farmers use pesticides, namely those that the pesticide will settle on the base and still allow the residue contained in the body of the fruit. Once believed to be clean, the sorting process is done to group oyster mushroom by shape and size. It aims to obtain results that are uniform so that will attract consumers when marketed.

\section{Packaging and Transport of Oyster Mushroom Harvest}

Packaging of fresh oyster mushrooms typically uses airtight plastic. The less air in the plastic, the more durable the oyster mushroom to be stored. However, ideally with airtight plastic storage can only maintain freshness oyster mushrooms for 2-4 days. Therefore, in order that fresh oyster mushrooms sold are in good condition, the process of transporting / transport should not be too long from the packaging process. Had transportation distance far enough, should be equipped with means of transport refrigerated room.

\section{Choosing Oyster Mushroom Seeds}

If you buy quality oyster mushroom seeds from other people, you also cannot fully trust them. You should still pay attention to the following things to avoid things you don't want. Check the BER (biological ratio) value of the seed. For oyster mushrooms usually, have about 75\% BER. The well-known institutions that I meant above are agencies that already have certificates or are legalized by the government. Mycelium grows fully and evenly. Check the expiration date again. Consult with those who have successfully cultivated oyster mushrooms. Of course, this is not easy, because you must at least be familiar with them. Oyster mushroom entrepreneurs who are already successful will certainly not easily share the recipe for their success with people they don't know who might later become their competitors.

In addition to knowing the types of oyster mushrooms and how to choose quality seeds, you also need to understand the growing media for oyster mushrooms. There are several ingredients that can be used to become a planting medium. Some of these ingredients are mixed together with a composition that suits the needs of the oyster mushroom. For this, you should look for many references about the composition that is right for the type of oyster mushroom that you will cultivate. These materials are wood powder, rice bran, CaCo lime, and water. The ideal composition should produce a planting medium which, if held, does not produce water, but if the disease do not break.

\section{Learn Oyster Mushroom Cultivation}

Okay, let's learn together about oyster mushroom cultivation and its prospects for business in the future. In Indonesia, there are a variety of edible mushrooms, you also know there are many types of mushrooms offered in supermarkets. But among the types of mushrooms, oyster mushrooms can be said to be one of the most beautiful mushrooms. Some even say that this oyster mushroom is the king of mushrooms in Indonesia.

This is due to the large public interest in consuming oyster mushrooms. Many dishes with oyster mushroom mixture are also delicious. Even in big cities, the potential of oyster mushrooms in dominating the food market can no longer be underestimated. How not, there is a countless number of crispy mushroom traders who use oyster mushrooms as one of the main ingredients. As if - oyster mushrooms have become a snack of 500 meters, which means that every 500 meters can be found traders of oyster mushrooms which are processed into snacks.

The high interest of Indonesians in oyster mushrooms makes oyster mushrooms one of the most sought-after food ingredients. Moreover, many food businesses that use oyster mushrooms are now using a franchise system. That means the business will be increasingly mushrooming, expanding to various regions. The areas that most often have oyster mushroom snacks are Mall, campus/school environment and food court. 
How? Increasingly interested in cultivating oyster mushrooms? Yep, some people are also tempted by the prospects of this business, most of them also do it with tools and places as simple as at home. As long as it is diligent and resilient, this business can become a land of money for you.

However, you should not rush into starting this business, because the most important thing is to enrich your knowledge first. Knowing the correct stages will minimize failure in business right? Maybe you've heard or read the opinion that cultivating oyster mushrooms is easy and can go straight as I wrote above. But you can remember that instant noodles need time to cook. Starting from reading cooking instructions, unwrapping, mixing spices, boiling water and the like. Easy things like cooking Instant Noodles also need to be studied, especially if the things you do concern your business and your future.

\section{Conclusion}

Alternative materials that can be used to replace the sawdust is a wide variety of grounds, such as coffee grounds, paper pulp, bagasse and dregs of tea. However, based on the experience of the oyster mushroom farmers in the lowlands, a good medium to use fixed sawdust.

Media in the form of bran/corn bran and flour serve as a substrate and a producer of calories for mold growth. Before buying bran and corn flour, you should first make sure these materials are new. If using materials that have long feared has happened fermentation which can result in the growth of unwanted fungi types. Based on the research results, the use of bran or corn teung delivers quality results for the same mushroom nutrient content of the two materials are similar. However, the use of bran is considered more efficient because it can cut costs and tend to be easy because many used as fodder. Limestone $(\mathrm{CaCO} 3)$ serves as a source of minerals and $\mathrm{pH}$ regulator. $\mathrm{Ca}$ content in the lime can neutralize the acid released mycelium fungus that can cause the $\mathrm{pH}$ of the media to be low.

Containers used to put the media mix is heat resistant clear plastic bag (PE 0,002) measuring $20 \mathrm{~cm} \mathrm{x} 30 \mathrm{~cm}$. The composition of seedling media is sawdust $100 \mathrm{~kg} ; 10 \mathrm{~kg}$ of maize flour; fine bran or bran $10 \mathrm{~kg} ; 0.5 \mathrm{~kg}$ of compost; limestone $(\mathrm{CaCO} 3) 0.5 \mathrm{~kg}$; and $50-60 \%$ water. There are two things to consider before planting seedlings mushroom, namely sterilization and sterilization material baglog.

\section{References}

Ardiansyah, R. A. (2016). Design of an electronic narrator on assistant robot for blind people. In MATEC Web of Conferences (Vol. 42, p. 03013). EDP Sciences.

Cahyana, M., \& Mucrodji, M. Bakrun. 1999. Pembibitan, Pembudidayaan dan Analisis Usaha Budidaya Jamur Tiram. Jakarta: Penebar Swadaya.

Djarijah, N. M., \& Djarijah, I. A. S. (2001). Budi Daya Jamur Kuping, Pembibitan Dan Pemeliharaan. Kanisius.

Gea-Izquierdo, G., Viguera, B., Cabrera, M., \& Cañellas, I. (2014). Drought induced decline could portend widespread pine mortality at the xeric ecotone in managed mediterranean pine-oak woodlands. Forest Ecology and Management, 320, 70-82. https://doi.org/10.1016/j.foreco.2014.02.025

Ginting, H., Näring, G., van der Veld, W. M., Srisayekti, W., \& Becker, E. S. (2013). Validating the Beck Depression Inventory-II in Indonesia's general population and coronary heart disease patients. International Journal of Clinical and Health Psychology, 13(3), 235-242. https://doi.org/10.1016/S1697-2600(13)70028-0

Hapsari, W. A., Umesh, A., Iwamura, M., Tomala, M., Gyula, B., \& Sebire, B. (2012). Minimization of drive tests solution in 3GPP. IEEE Communications Magazine, 50(6), 28-36.

Muchtadi, T. R., \& Ayustaningwarno, F. (2010). Teknologi proses pengolahan pangan. Alfabeta. Bandung, 246.

Parjimo, H., \& Andoko, A. (2013). Budi Daya Jamur (Jamur Kuping, Jamur Tiram, Jamur Merang). AgroMedia.

Sumarni, M., \& Wahyuni, S. (2006). Metodologi penelitian bisnis. Yogyakarta: CV. Andi Offset.

Sumarsih, S. (2010). Untung besar usaha binit jamur tiram. PT Niaga Swadaya. 